\title{
Adherence of Mycoplasma gallisepticum to Human Erythrocytes
}

\author{
M. BANAI, ${ }^{1}$ I. KAHANE, ${ }^{1}$ S. RAZIN, ${ }^{1 *}$ AND W. BREDT ${ }^{2}$ \\ Biomembrane Research Laboratory, Department of Clinical Microbiology, The Hebrew University. \\ Hadassah Medical School, Jerusalem, Israel, ${ }^{1}$ and Institute for General Hygiene and Bacteriology, Center \\ for Hygiene, Albert-Ludwigs-Universität, D-7800 Freiburg, West Germany ${ }^{2}$
}

Received for publication 7 February 1978

\begin{abstract}
Pathogenic mycoplasmas adhere to and colonize the epithelial lining of the respiratory and genital tracts of infected animals. An experimental system suitable for the quantitative study of mycoplasma adherence has been developed by us. The system consists of human erythrocytes (RBC) and the avian pathogen Mycoplasma gallisepticum, in which membrane lipids were labeled. The amount of mycoplasma cells attached to the RBC, which was determined according to radioactivity measurements, decreased on increasing the $\mathrm{pH}$ or ionic strength of the attachment mixture. Attachment followed first-order kinetics and depended on temperature. The mycoplasma cell population remaining in the supernatant fluid after exposure to RBC showed a much poorer ability to attach to $\mathrm{RBC}$ during a second attachment test, indicating an unequal distribution of binding sites among cells within a given population. The gradual removal of sialic acid residues from the $R B C$ by neuraminidase was accompanied by a decrease in mycoplasma attachment. Isolated glycophorin, the RBC membrane glycoprotein carrying almost all the sialic acid moieties of the RBC, inhibited $M$. gallisepticum attachment, whereas asialoglycophorin and sialic acid itself were very poor inhibitors of attachment. Only part of the ${ }^{125}$ I-labeled glycophorin bound to mycoplasmas could be removed by neuraminidase or by exchange with unlabeled glycophorin. It is suggested that glycophorin, representing the isolated major RBC receptor for $M$. gallisepticum, binds to the mycoplasmas both specifically, through its sialic acid moieties, and nonspecifically, through its exposed hydrophobic polypeptide moiety.
\end{abstract}

The adherence of parasitic mycoplasmas to eucaryotic cell surfaces, both in vivo and in vitro, or to inert surfaces such as glass and plastic is a well-established phenomenon $(4,5,7,9,10,14$, $15,17,19,20-22)$. Since the pathogenic mycoplasmas are mostly located on the epithelial surfaces of the respiratory and genital tracts of their hosts, the importance of studies on the adherence phenomenon to the understanding of mycoplasma pathogenicity cannot be overestimated. Unfortunately, most of the information available so far on this subject comes from qualitative rather than quantitative studies, based mostly on the direct demonstration of adherence by light or electron microscopy $(2,4,7,9,15,22$, 24) and by studies on the adherence of mycoplasmas to erythrocytes (RBC), as manifested either by agglutination of RBC by mycoplasmas (hemagglutination) or by the adsorption of RBC to mycoplasma colonies (hemadsorption) $(7,10$, $14,19)$. Only during the last few years has a more rigorous assessment of mycoplasma adherence become available through the use of my- coplasmas in which cell protein, membrane lipids, or nucleic acids were labeled by radioactive amino acids, fatty acids, or nucleic acid precursors, respectively $(5,17)$.

Our major aim is to chemically define the receptors on the host cell and the binding sites on the mycoplasma cells responsible for adherence. As a first step towards reaching this goal, an effort was made to devise an experimental system in which adherence can be determined quantitatively under strictly defined conditions. Mycoplasma gallisepticum and human RBC were selected for this purpose. The avian pathogen $M$. gallisepticum was chosen as our first test organism because it has a very pronounced hemagglutinating capacity. In addition, it grows quickly and its cell and membrane components can be easily labeled with nucleic acid, protein, or lipid precursors during growth. Moreover, the receptor sites for $M$. gallisepticum on the RBC membrane appear to contain sialic acid as specific determinants $(7,15)$, suggesting that glycophorin, the major sialoglycoprotein of RBC 
membranes $(11,16)$, serves as a receptor site for $M$. gallisepticum. The availability of purified glycophorin has enabled studies on its interaction with $M$. gallisepticum cells, the results of which are reported in this communication.

\section{MATERIALS AND METHODS}

Organisms and growth conditions. M. gallisepticum (A5969) was grown in a modified Edward medium (18) containing 4\% horse serum and either 100 $\mu \mathrm{Ci}$ of $\left[9,10^{-3} \mathrm{H}\right]$ palmitic acid (The Radiochemical Centre, Amersham, England) or $500 \mu \mathrm{Ci}$ of [methyl$\left.{ }^{3} \mathrm{H}\right]$ thymidine (Nuclear Research Center, Negev, Israel) per liter. The organisms were harvested after 18 to $20 \mathrm{~h}$ at $37^{\circ} \mathrm{C}$, at which point the absorbance of the culture at $640 \mathrm{~nm}$ reached 0.18 to 0.25 . The organisms were washed once with $0.1 \mathrm{M} \mathrm{NaCl}$ containing $1 \mathrm{mM}$ $\mathrm{CaCl}_{2}$ and $0.05 \mathrm{M}$ tris(hydroxymethyl)aminomethane (Tris), pH 7.2 (buffer A), resuspended in the same buffer solution to about $1 \mathrm{mg}$ of cell protein per $\mathrm{ml}$, and used in the same day.

RBC. Fresh human blood (AB or $\mathrm{O}$ blood type) was withdrawn into citrate anticoagulant and was used within 1 week. The blood was washed three times in buffer $A$ by centrifuging at $370 \times g$ for $5 \mathrm{~min}$. The washed RBC pellet was resuspended in the same buffer to give a $2 \%$ (vol/vol) packed-cell suspension.

Neuraminidase treatment. Fresh human blood was washed with phosphate-buffered saline, pH 7.0, three times by the same procedure mentioned above. The washed RBC were resuspended in phosphatebuffered saline supplemented with $1 \mathrm{mM} \mathrm{CaCl} 2$ to give a $10 \%$ (vol/vol) packed-cell suspension. This suspension was treated with various concentrations $(0.1$ to 20 $\mathrm{U} / \mathrm{ml}$ ) of Vibrio cholerae neuraminidase (Behringwerke AG, Marburg-Lahn, Germany) for periods of 5 to $120 \mathrm{~min}$ at $37^{\circ} \mathrm{C}$. The reaction was stopped by centrifugation of the mixture for $5 \mathrm{~min}$ at $370 \times \mathrm{g}$, and samples of the supernatant fluid were taken for sialic acid determination. The treated RBC pellet was washed twice with buffer $A$ and was then resuspended in the same buffer to give a $2 \%(\mathrm{vol} / \mathrm{vol})$ packed-cell suspension.

Glycophorin. Glycophorin, the major sialoglycoprotein of the RBC membranes, was isolated and purified according to Marchesi and Andrews (16), and the purified protein was iodinated with carrier free ${ }^{125} \mathrm{I}$ (Amersham) following the procedure of Kahane et al. (11). Asialoglycophorin was derived from the purified glycophorin by acid hydrolysis $\left(0.1 \mathrm{~N} \mathrm{HCl}, 80^{\circ} \mathrm{C}\right.$ for 1 h) according to Ben-Shitrit and Kahane (unpublished data).

Siliconization of test tubes. Two hundred milliliters of dimethyl polysiloxane (Sigma) was added to $1,000 \mathrm{ml}$ of carbon tetrachloride. The solution was transferred from one serological (borosilicate glass) test tube to another. The test tubes were inverted and kept in this position overnight at room temperature and then heated in an oven at $120^{\circ} \mathrm{C}$ for $6 \mathrm{~h}$.

Assessment of mycoplasma attachment. An attachment mixture consisting of $0.05 \mathrm{ml}$ of a $2 \%$ RBC suspension (about $1 \times 10^{7}$ to $5 \times 10^{7}$ cells) and $0.1 \mathrm{ml}$ of the mycoplasma cell suspension in buffer $A$ (about $1 \times 10^{8}$ to $2 \times 10^{8}$ cells, containing 10 to $20 \mu \mathrm{g}$ of protein) was incubated with shaking in a siliconized test tube for $30 \mathrm{~min}$ at $37^{\circ} \mathrm{C}$. Controls in which $\mathrm{RBC}$ suspensions were replaced by $0.05 \mathrm{ml}$ of buffer $A$ were included. After incubation, $0.5 \mathrm{ml}$ of cold buffer $A$ was added, and the suspension was centrifuged at 1,000 rpm for 1 min in a Sorvall GLC-2 centrifuge, using a swing-out bucket rotor. The supernatant was discarded, and the pellet was washed twice by using the same procedure. The washed pellet was resuspended in $0.3 \mathrm{ml}$ of cold buffer $\mathrm{A}$ and transferred to a nonsiliconized test tube; the same was done in the control test tube without $R B C$, in which a pellet was not discernible. A solution of $1 \%$ sodium dodecyl sulfate $(0.1 \mathrm{ml})$ followed by $0.1 \mathrm{ml}$ of $1 \% \mathrm{H}_{2} \mathrm{O}_{2}$ was added to the suspension, which was then left overnight at room temperature. Duplicate samples $(0.2 \mathrm{ml}$ each) were then transferred to scintillation vials for counting.

Attachment capacity of mycoplasmas preexposed to RBC. Attachment tests were performed in 10 test tubes with $50 \mu \mathrm{g}$ of $M$. gallisepticum cell protein in each. After $30 \mathrm{~min}$ of incubation at $37^{\circ} \mathrm{C}, 0.2 \mathrm{ml}$ of cold buffer $A$ was added to each test tube, and the mixture was centrifuged for $1 \mathrm{~min}$ at $1000 \mathrm{rpm}$ in the GLC-2 centrifuge. The supernatant fluid was separated and pooled to be used for an additional attachment test. A suspension of $M$. gallisepticum cells, not exposed to RBC and diluted to give the same protein concentration as the suspension of the exposed cells, served as a control. The second attachment test was performed according to the usual procedure, as described above.

Inhibition of mycoplasma attachment to RBC. Several compounds were tested for inhibition of the attachment of M. gallisepticum to RBC. Among these were: $N$-acetylneuraminic acid from various sources (Sefochem, Fine Chemicals, Ltd., Emek-Hayarden, Israel; Boehringer, Mannheim, Germany; Sigma, St. Louis, Mo., synthetic and from Escherichia coli), glycophorin isolated from human RBC membranes, and asialoglycoprotein prepared from glycophorin. Various amounts of these compounds $(0.1$ to $200 \mu \mathrm{g})$ were added to the attachment mixture. In most experiments the inhibitor was added to the attachment mixture simultaneously with the mycoplasmas and the RBC, but in some experiments the inhibitor was preincubated with the mycoplasmas for $30 \mathrm{~min}$ at $37^{\circ} \mathrm{C}$ or was added after the mycoplasmas were incubated with the RBC.

Binding of glycophorin and asialoglycophorin to M. gallisepticum. Approximately $40 \mu \mathrm{g}$ of the iodinated glycophorin or asialoglycophorin (with specific radioactivity ranging from $8 \times 10^{4}$ to $1 \times 10^{6}$ $\mathrm{cpm} / \mu \mathrm{g}$ ) was incubated at $37^{\circ} \mathrm{C}$ for $30 \mathrm{~min}$ with different amounts of $M$. gallisepticum cells in a total volume of $2 \mathrm{ml}$ of buffer A. Incubation was terminated by centrifugation at $27,000 \times g$ for $20 \mathrm{~min}$, and the pellet was washed two times with $2 \mathrm{ml}$ of buffer $A$. The washed pellet was resuspended in $4.5 \mathrm{ml}$ of buffer $A$, and the suspension was divided into three equal parts. One part received $0.1 \mathrm{ml}$ of buffer A containing 440 $\mu \mathrm{g}$ of unlabeled glycophorin, the other part received $0.1 \mathrm{ml}$ of buffer A containing $75 \mathrm{U}$ of neuraminidase, and the third part, which served as a control, received $0.1 \mathrm{ml}$ of buffer $\mathrm{A}$ with no addition. After incubation at $37^{\circ} \mathrm{C}$ for $1 \mathrm{~h}$, the cells were collected by centrifu- 
gation and washed twice as described above. The washed pellets were resuspended in buffer $A$ to a final volume of $1 \mathrm{ml}$, and aliquots were taken for protein and radioactivity measurements.

Analytical procedures. Protein was determined by the technique of Lowry et al. (13). To determine sialic acid content in neuraminidase-treated $\mathrm{RBC}$, the membranes of the treated cells were isolated by osmotic lysis of the RBC (11) and washed, and aliquots containing 150 to $300 \mu \mathrm{g}$ of membrane protein were hydrolyzed in $0.1 \mathrm{M} \mathrm{H}_{2} \mathrm{SO}_{4}$ for $1 \mathrm{~h}$ at $80^{\circ} \mathrm{C}$. The hydrolysate was analyzed for sialic acid by the thiobarbituric acid assay of Warren (23) as modified by Aminoff (1). Sialic acid in membranes of RBC treated with neuraminidase was also assessed by gas-liquid chromatography by a modification of the method of Clamp (3), using 3\% SE-30 on a Gas Chrom Q column ( $2.5 \mathrm{~m}$ by $3.2 \mathrm{~mm}$ in diameter). The initial temperature of chromatography was $170^{\circ} \mathrm{C}$, increasing $1^{\circ} \mathrm{C} / \mathrm{min}$ up to $200^{\circ} \mathrm{C}$, with an additional $20 \mathrm{~min}$ at this temperature. Radioactivity of tritium-labeled isotopes was determined by scintillation spectrometry using a Triton $\mathrm{X}$-100-toluene liquor (12), whereas ${ }^{125} \mathrm{I}$ was counted by gamma scintillation spectrometry.

\section{RESULTS}

Assessment of mycoplasma attachment to RBC. Two problems had to be solved before the amount of mycoplasmas attaching to RBC could be determined. The first was quantifying the low number of mycoplasma cells attaching to the $\mathrm{RBC}$, and the second was reducing the number of mycoplasmas attaching to the glass surface of the test tube. To increase the sensitivity of the determination of mycoplasma attachment, the organisms were labeled by growing them in the presence of $\left[{ }^{3} \mathrm{H}\right]$ palmitic acid. This fatty acid was incorporated into membrane lipids more effectively than radioactive oleic acid. The radioactivity values were correlated with cell protein for each batch of organisms so that the amount (expressed as micrograms of cell protein) of mycoplasma cells attached to the RBC could be derived from the radioactivity values found associated with the RBC. The possibility that labeled mycoplasma membrane lipids were rapidly exchanged with the $\mathrm{RBC}$ lipids (17), a factor which could interfere with the correct assessment of mycoplasma attachment, was ruled out by showing that the attachment values obtained with $\left[{ }^{3} \mathrm{H}\right]$ thymidine-labeled $M$. gallisepticum were the same as those obtained with the $\left[{ }^{3} \mathrm{H}\right]$ palmitate-labeled mycoplasmas.

The attachment of the mycoplasmas to the glass walls of the reaction tube was found to decrease significantly when the glass surface was coated with silicone. The percentage of mycoplasmas adhering to the test tube decreased from 30 to about $10 \%$ after siliconization.

Attachment as a function of the amount of mycoplasmas and RBC. Figure 1 shows that attachment of the mycoplasmas to a constant amount of RBC increased linearly as the amount of mycoplasma cells in the attachment mixture increased. This linearity was maintained at least up to a content of $50 \mu \mathrm{g}$ of mycoplasma protein per test tube. When the amount of mycoplasma cells was kept constant and the amount of $\mathrm{RBC}$ was varied, attachment reached a plateau of about $3 \mu \mathrm{g}$ of mycoplasma cell protein (Fig. 1).

The percentage of mycoplasmas attached of the total mycoplasmas present in the attachment mixture did not change significantly when the amount of mycoplasma cells in the attachment mixture ranged from about $10 \mu \mathrm{g}$ to about $50 \mu \mathrm{g}$ of protein (Table 1). The percentage of mycoplasma cells attached, though constant in specific experiments, varied among different experiments from about 8 to $20 \%$ of the total. Of the unattached mycoplasma cells, about 5 to $10 \%$ were found attached to the siliconized test tubes. It also appears that the RBC compete with the test tube wall for the attachment of the mycoplasmas, since the amount of the mycoplasmas attached to the test tube walls in the absence of RBC was up to $40 \%$ higher than in the presence of $\mathrm{RBC}$.

Effects of temperature and kinetics of attachment. The kinetics of mycoplasma attachment to RBC were studied at different temperatures. The attachment curves appear to follow first-order kinetics and to be influenced by temperature (Fig. 2). Although, due to technical difficulties, the comparison of rates during the first 5 min was not sufficiently accurate, it is clear that after longer incubation periods attachment increased with temperature. The maximum attachment value obtained at $37^{\circ} \mathrm{C}$ after 35 min (Fig. 2) did not change significantly on further incubation at the same temperature for another $50 \mathrm{~min}$. Consequently, incubation for 30 min at $37^{\circ} \mathrm{C}$ was selected as standard procedure in all subsequent experiments.

Effect of ionic strength, $\mathrm{pH}$, and divalent cations on attachment. Attachment was found to decrease on increasing the ionic strength of the attachment mixture (Fig. 3). At $\mathrm{NaCl}$ concentrations higher than $1.1 \mathrm{M}$, the RBC lysed. To test the effect of $\mathrm{pH}$ on attachment, $0.05 \mathrm{M}$ Tris-maleate buffer replaced the usual Tris buffer in the attachment mixture. Gradually increasing the $\mathrm{pH}$ from 6.0 to 9.0 caused a continuous decrease in the attachment values, so that the attachment at $\mathrm{pH} 9.0$ was about 20 to $30 \%$ lower than at pH 6.0. At pH values lower than 6.0 , the $\mathrm{RBC}$ lysed. The addition of $\mathrm{Ca}^{2+}$ or $\mathrm{Mg}^{2+}$ to the attachment mixture at concentrations ranging from $10^{-5}$ to $10^{-2} \mathrm{M}$ did not affect the attachment of mycoplasmas to 


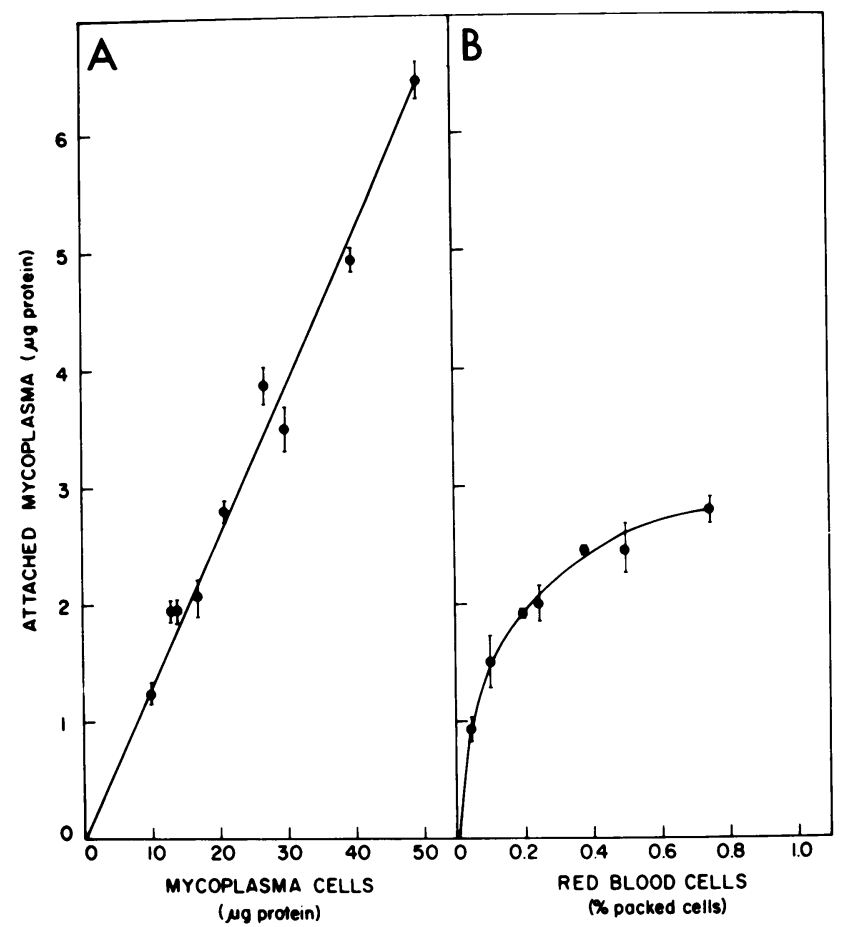

FIG. 1. Attachment of M. gallisepticum to human RBC as a function of the amount of mycoplasmas in the standard attachment mixture containing RBC in a final concentration of $0.67 \%$ packed cells $(A)$, or as a function of the concentration of $R B C$ in an attachment mixture containing $20 \mu g$ of mycoplasma cells per tube (B). Data for (A) were collected from 20 different experiments, and for (B) from 3 different experiments. Bars represent the standard deviation of the mean.

TABle 1. Percentage of mycoplasma cells attached to the $R B C$ as a function of varying the mycoplasma cell concentration in the attachment mixture

\begin{tabular}{|c|c|c|}
\hline $\begin{array}{l}\text { Mycoplasmas in at- } \\
\text { tachment mixture } \\
\text { ( } \mathrm{g}_{\mathrm{g} \text { of cell protein/ }} \\
\text { tube) }\end{array}$ & $\begin{array}{c}\text { Mycoplasmas at- } \\
\text { tached ( } \mu \mathrm{g} \text { of cell } \\
\text { protein) }\end{array}$ & $\begin{array}{l}\text { Mycoplasmas at- } \\
\text { tached of total in } \\
\text { tube (\%) }\end{array}$ \\
\hline 13 & 2.15 & 16.3 \\
\hline 18 & 3.12 & 17.4 \\
\hline 27 & 3.84 & 14.3 \\
\hline 38 & 5.32 & 13.8 \\
\hline 49 & 7.15 & 14.4 \\
\hline
\end{tabular}

a The attachment mixture contained the standard $0.67 \%$ packed RBC.

RBC. Nevertheless, the inclusion of $12 \mathrm{mM}$ ethylenediaminetetraacetate or ethyleneglycolbis(2-aminoethyl ether)- $N, N^{\prime}$-tetraacetate in the attachment mixture decreased the attachment values by 20 to $50 \%$.

Attachment capacity of $M$. gallisepticum cells preexposed to $\mathbf{R B C}$. The $M$. gallisepticum cell population remaining in the supernatant fluid after exposure to RBC showed a much poorer capacity to attach to RBC during a second attachment test when compared with mycoplasma cell suspensions which had not previ- ously been exposed to RBC (Table 2).

Attachment of mycoplasmas to neuraminidase-treated RBC. The decrease in the RBC sialic acid content after their treatment with various concentrations of $V$. cholerae neuraminidase was accompanied by a decrease in the amount of mycoplasmas attached to the treated RBC (Fig. 4). Attachment decreased exponentially with the release of sialic acid from the RBC. Nevertheless, the attachment capacity of the RBC did not decrease below $20 \%$ of the capacity of untreated RBC even under the most extensive neuraminidase treatment. It can be seen from the figure that the attachment capacity of the RBC decreased to some extent even on treatment with very low neuraminidase concentrations, although no sialic acid could be detected colorimetrically in the supernatant fluids. Variations in the attachment capacity of RBC from which the same amount of sialic acid was released were found even for the same batch of cells treated separately with neuraminidase (Fig. 4). Sialic acid determination in the treated RBC membranes indicated that under these conditions at least $5 \%$ of the original sialic acid remained in the $\mathrm{RBC}$, as determined by gasliquid chromatography. 


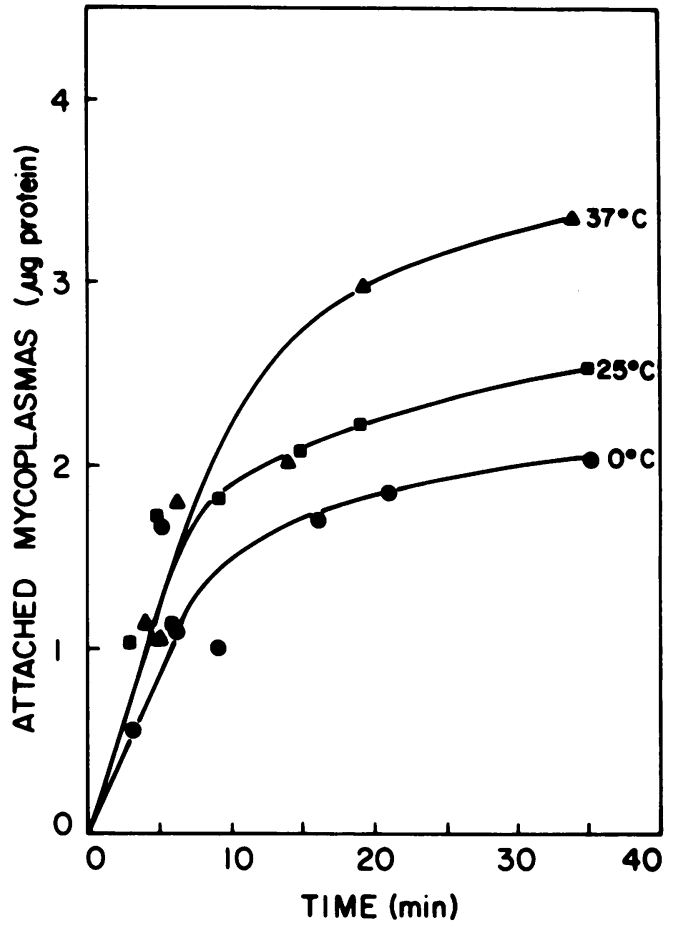

FIG. 2. Kinetics of M. gallisepticum attachment to $R B C$ at different temperatures. Attachment was tested in the standard attachment mixture. Data from a representative experiment.

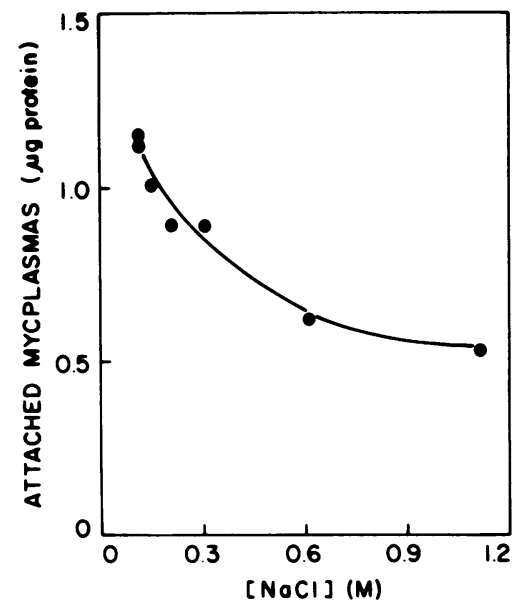

FIG. 3. Effect of ionic strength on M. gallisepticum attachment to $R B C$. Data from a representative experiment.

Attachment inhibitors. As the major receptors on the $\mathrm{RBC}$ responsible for the attachment of $M$. gallisepticum apparently contain sialic acid, experiments were carried out to test whether attachment can be abolished by adding compounds containing sialic acid to the attachment mixture. Different batches of carefully
TABLE 2. Difference in the attachment capacity of M. gallisepticum populations before and after exposure to $R B C$

\begin{tabular}{|c|c|c|}
\hline Population tested & $\begin{array}{l}\text { Mycoplasmas in } \\
\text { attachment mix- } \\
\text { ture ( } \mu \mathrm{g} \text { of cell } \\
\text { protein/tube) }\end{array}$ & 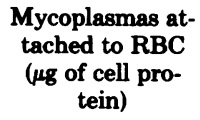 \\
\hline Original population & $\begin{array}{r}9.7 \\
16.7\end{array}$ & $\begin{array}{l}0.77 \\
1.45\end{array}$ \\
\hline $\begin{array}{l}\text { After exposure to } \\
\mathrm{RBC}^{a}\end{array}$ & $\begin{array}{r}7.2 \\
11.4\end{array}$ & $\begin{array}{l}0.07 \\
0.18\end{array}$ \\
\hline
\end{tabular}

${ }^{a}$ Population fraction remaining unattached after preexposure to $\mathrm{RBC}$ for $30 \mathrm{~min}$ at $37^{\circ} \mathrm{C}$. Results of one representative experiment out of four.

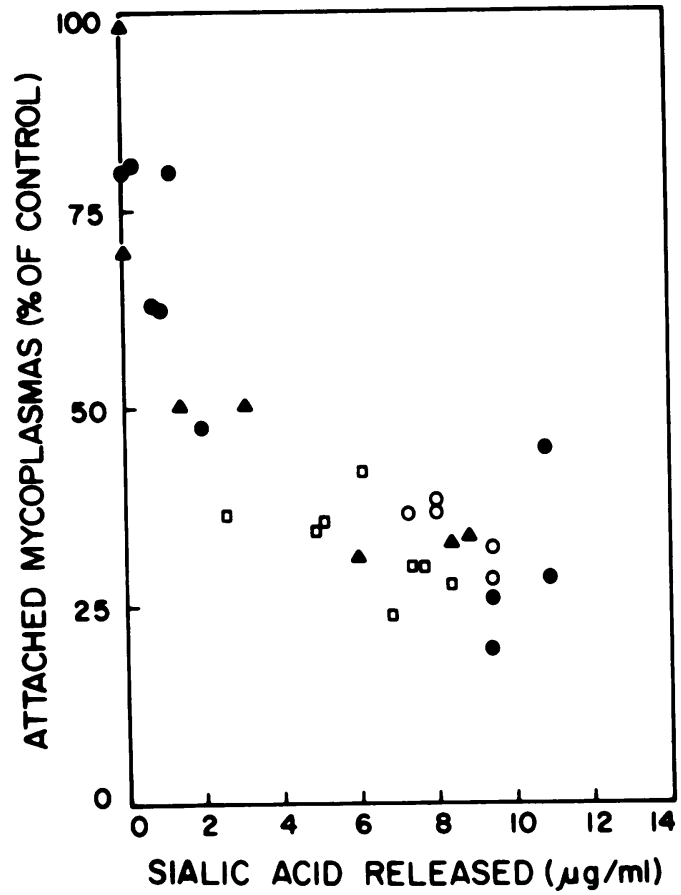

Fig. 4. Effects of sialic acid removal from $R B C$ on their ability to attach $M$. gallisepticum. The $R B C$ were treated with various concentrations of $V$. cholerae neuraminidase for different periods of time, as described in the text. The sialic acid released was determined colorimetrically in the supernatant fluids remaining after sedimentation of the treated $R B C$. Results are of several experiments, using four batches of cells (depicted in different symbols), and are expressed as percentage of attachment to treated $R B C$ as compared with attachment to untreated $R B C$.

neutralized $N$-acetylneuraminic acid failed to inhibit attachment at concentrations up to 200 $\mu \mathrm{g} /$ test tube $(1 \mathrm{mg} / \mathrm{ml})$. Glycophorin, on the other hand, was found to be a very effective inhibitor, particularly when preincubated with the mycoplasmas prior to the addition of the RBC (Table 3). However, the washing of the 
mycoplasmas preexposed to glycophorin reduced the inhibitory effect, and the addition of glycophorin after the exposure of the mycoplasmas to RBC had little effect on the attachment values (Table 3). Asialoglycophorin, a derivative of glycophorin from which the sialic acid residues were removed by acid hydrolysis, inhibited $M$. gallisepticum attachment to RBC by only $10 \%$ when $50 \mu \mathrm{g}$ of it was added in the attachment mixture.

Binding of $\left[{ }^{125} \Pi\right.$ glycophorin to $M$. gallisepticum. To test for the nature of the association between glycophorin and $M$. gallisepticum cells, labeled glycophorin or asialoglycophorin was incubated with the mycoplasmas. The amount of iodinated glycophorin which remained bound to the mycoplasmas after extensive washings (four washes with buffer $A$ ) varied between 1 and $6 \mu \mathrm{g}$ of glycophorin per $\mathrm{mg}$ of mycoplasma cell protein. Table 4 shows that only part of the bound $\left.{ }^{125} \mathrm{I}\right] \mathrm{glyc}$ cophorin could be released by neuraminidase treatment or by exchange with unlabeled glycophorin. The amounts of $\left[{ }^{125} \mathrm{I}\right]$ asialoglycophorin bound to $M$. gallisepticum were much smaller than those of $\left[{ }^{125} \mathrm{I}\right]$ glycophorin bound, and the asialoglycophorin bound could not be released to any significant degree by neuraminidase or by exchange with glycophorin (Table 4).

\section{DISCUSSION}

The amount of $M$. gallisepticum cells attached to RBC was found to be linearly dependent on the amount of the mycoplasmas in the

TABLE 3. Effects of various modes of treatment with glycophorin on the attachment of $M$. gallisepticum to $R B C$

\begin{tabular}{|c|c|c|}
\hline Treatment & $\begin{array}{l}\text { Glycophorin } \\
\text { added per } \\
\text { tube ( } \mu \mathrm{g})\end{array}$ & $\begin{array}{l}\text { Mycoplasmas at- } \\
\text { tached (\% of con- } \\
\text { trol with no gly- } \\
\text { cophorin) }\end{array}$ \\
\hline $\begin{array}{l}\text { 30-min preincubation } \\
\text { with glycophorin be- } \\
\text { fore attachment test }\end{array}$ & $\begin{array}{r}3 \\
50\end{array}$ & $\begin{array}{l}37 \\
12\end{array}$ \\
\hline $\begin{array}{l}\text { 30-min preincubation } \\
\text { with glycophorin fol- } \\
\text { lowed by two wash- } \\
\text { ings before attach- } \\
\text { ment test }\end{array}$ & $\begin{array}{r}3 \\
50\end{array}$ & $\begin{array}{l}95 \\
47\end{array}$ \\
\hline $\begin{array}{l}\text { Glycophorin added si- } \\
\text { multaneously with } \\
\text { RBC }\end{array}$ & $\begin{array}{r}3 \\
50\end{array}$ & $\begin{array}{l}53 \\
54\end{array}$ \\
\hline $\begin{array}{l}\text { Glycophorin added } \\
\text { after attachment to } \\
\text { RBC with additional } \\
\text { incubation for } 30 \mathrm{~min}\end{array}$ & $\begin{array}{r}3 \\
50\end{array}$ & $\begin{array}{l}88 \\
89\end{array}$ \\
\hline
\end{tabular}

TABLE 4. Binding of $\left[{ }^{125} I\right] g l y c o p h o r i n$ and $\left[{ }^{125} I\right]$ asialoglycophorin to M. gallisepticum cells ${ }^{a}$

\begin{tabular}{|c|c|c|}
\hline Condition & 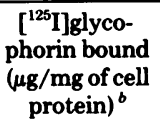 & 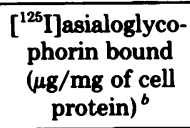 \\
\hline $\begin{array}{l}\text { Binding with no addi- } \\
\text { tional treatment }\end{array}$ & 2.70 & 0.74 \\
\hline $\begin{array}{l}\text { Binding followed by } \\
\text { treatment with unla- } \\
\text { beled glycophorin }^{c}\end{array}$ & 1.50 & 0.64 \\
\hline $\begin{array}{l}\text { Binding followed by } \\
\text { treatment with neur- } \\
\text { aminidase }^{c}\end{array}$ & 1.86 & 0.60 \\
\hline
\end{tabular}

${ }^{a}$ The data represent the mean values of two experiments.

${ }^{b}$ Calculated from specific radioactivity values.

c Experimental details in Materials and Methods.

experimental system (Fig. 1), indicating that even at the highest concentration of mycoplasma cells tested (equivalent to $50 \mu \mathrm{g}$ of cell protein per test tube) the receptor sites on the RBC $(0.67 \%$ packed cells) were not saturated. Hence, the amount of mycoplasma used in most of the attachment tests is well within this linear region, and under our experimental conditions the amount of mycoplasmas attached depended on their amount in the attachment mixture, rather than on the amount of $R B C$ in the test tube. The finding that the percentage of mycoplasmas attached to the RBC of the total mycoplasmas in the attachment mixture was essentially constant (Table 1) suggests that the mycoplasma cell suspension consists of two populations, one of which has a much higher avidity for attachment to the RBC than the other. The experiment summarized in Table 2 provides strong support for this suggestion. Whether the difference between the populations results from differences in cell viability, physiological age, loss or masking of binding sites by extracellular components, or uneven distribution of binding sites on cells requires further study.

Our experimental system has a clear advantage over the hemagglutination system for testing kinetics of attachment. Hemagglutination depends both on the presence of a high content of mycoplasmas in the agglutination mixture and on a rather long incubation period. In our system, mycoplasma attachment to the RBC can be studied independently of the hemagglutination phenomenon. We found the attachment of $M$. gallisepticum to the RBC to be temperature dependent and to follow first-order kinetics. Dependence of mycoplasma attachment on temperature has also been noted by others $(9,14)$, and the attachment of $M$. pneumoniae to tracheal rings was found by Powell et al. (17) to 
follow first-order kinetics. The kinetics and temperature dependence of mycoplasma attachment are characteristic of an adsorption process in which the number of particles adsorbed at any given time is dependent on the frequency of their collision.

The decrease in $M$. gallisepticum attachment to $\mathrm{RBC}$ on increasing the ionic strength or the $\mathrm{pH}$ of the attachment mixture indicates that electrostatic bonds participate in mycoplasma adherence, though they cannot be the sole bonds involved. The increased mycoplasma attachment at low $\mathrm{pH}$ could accordingly be explained by the fact that the sialic acid residues on the RBC taking part in $M$. gallisepticum attachment have a very low pK (about 2.5) so that they are negatively charged at $\mathrm{pH} 6.0$, whereas at this $\mathrm{pH}$ the dissociation of the basic amino groups on the mycoplasma cell surface increases, thus intensifying electrostatic bond formation between the mycoplasmas and the RBC.

Though it is apparently well established that sialic acid moieties on the eucaryotic cell surface serve as receptors for the attachment of $M$. gallisepticum, $M$. pneumoniae, and $M$. synoviae $(7,15,19)$, it is still unclear whether they are the sole receptors for these mycoplasmas. Our system enabled a more rigorous and quantitative approach for testing this problem. The most extensive neuraminidase treatment of the RBC failed to completely remove the sialic acid moieties of the RBC. Hence, the residual capacity of the treated RBC to attach $M$. gallisepticum (about 20\% of that of untreated RBC) could still be attributed to residual sialic acid moieties.

Despite the above indications that sialic acid moieties are the major if not the only receptors on the RBC, sialic acid itself, from different sources, failed to inhibit attachment when added to the attachment mixture before or together with the RBC. This result differs from that of Gesner and Thomas (7), who reported the inhibition by sialic acid of hemagglutination by $M$. gallisepticum. However, their experimental conditions as well as their source of RBC were different from ours. Furthermore, Gesner and Thomas (7) stress that the inhibitory effect of sialic acid could be demonstrated only within a narrow range of concentrations and depended on the amount of mycoplasmas in the reaction mixture. We have found that it is extremely important to carefully neutralize the sialic acid used in the inhibition tests. The finding that high concentrations ( $4 \%$, by weight) of sialic acid inhibited attachment of $M$. pneumoniae to RBC (9) could not be reproduced with neutralized sialic acid (Bredt and Feldner, unpublished data). Preliminary studies (Kahane, unpub- lished data) suggest that the binding site of $M$. gallisepticum to RBC is of a protein nature, and since it specifically binds to sialic acid-containing receptors, it can be regarded as a microbial lectin. The failure of sialic acid, by itself, to block the binding site finds its parallel in the poor ability of monosaccharides to block lectins, as compared to higher-molecular-weight compounds containing the monosaccharide specific for the lectin.

The finding that sialic acid moieties are responsible for most, if not all, of mycoplasma attachment to human $\mathrm{RBC}$ indicates that the specific receptor on the RBC membrane is glycophorin, the glycoprotein which carries over $90 \%$ of the sialic acid residues of the RBC (11). Glycophorin is one of the best characterized membrane proteins; it can be readily isolated and purified, and its structure is well established $(11,16)$. Obviously, the availability of the specific receptor for $M$. gallisepticum attachment to RBC opens many possibilities for investigating its interaction and mode of binding to the mycoplasma cell. The results presented in this report show that glycophorin binds to $M$. gallisepticum cells, and, when added in excess prior to the RBC, it almost completely inhibits the attachment of the mycoplasmas to the RBC (Table 3). That some of the glycophorin attaches very firmly to the mycoplasmas has been indicated in the experiments using labeled glycophorin (Table 4). Only a part of the tightly bound glycophorin could be detached from the mycoplasmas by neuraminidase or by exchange with unlabeled glycophorin. The interpretation of these results can be based on the fact that the isolated glycophorin, being an integral membrane protein, forms micelles in aqueous solution, because once isolated the hydrophobic portion of the glycophorin molecule is exposed. The isolated glycophorin could thus be expected to attach to the mycoplasma membrane not only through its sialic acid moieties, but also nonspecifically through the hydrophobic portion of its molecule. In fact, our data show that iodinated asialoglycophorin binds also to $M$. gallisepticum, though to a much smaller extent than glycophorin. This brings us to the question of how tight the attachment of the mycoplasmas to the RBC is. We could show that mycoplasmas which remained attached to the RBC after our standard washing procedure did not detach from the RBC during an additional incubation period of $1 \mathrm{~h}$ at $37^{\circ} \mathrm{C}$. Furthermore, treatment with neuraminidase also failed to detach the mycoplasmas bound to the RBC. This can be taken to suggest that additional bonds, probably of the London-van der Waals type (8), are formed be- 
tween the mycoplasmas and the host membrane components after the initial attachment of the mycoplasmas to the specific sialic acid-containing receptor sites.

\section{ACKNOWLEDGMENTS}

This investigation was supported by grant $\mathrm{Br} 296 / 9$ from the Deutsche Forschungsgemeinschaft, Germany.

\section{LTTERATURE CITED}

1. Aminoff, D. 1961. Methods for the quantitative estimation of $\mathrm{N}$-acetylneuraminic acid and their application to hydrolysates of sialomucoids. Biochem. J. 81:384-391.

2. Apostolov, K., and G. D. Windsor. 1975. The interaction of Mycoplasma gallisepticum with erythrocytes. 1. Morphology. Microbios 13:205-215.

3. Clamp, J. R. 1974. Analysis of glycoproteins. Biochem. Soc. Symp. 40:3-16.

4. Collier, A. M., and W. A. Clyde, Jr. 1971. Relationships between Mycoplasma pneumoniae and human respiratory epithelium. Infect. Immun. 3:694-701.

5. Engelhardt, J. A., and M. G. Gabridge. 1977. Effect of squamous metaplasia on infection of hamster trachea organ cultures with Mycoplasma pneumoniae. Infect. Immun. 15:647-655.

6. Gabridge, M. G., Y. D. B. Stahl, R. B. Polisky, and J. A. Engelhardt. 1977. Differences in the attachment of Mycoplasma pneumoniae cells and membranes to tracheal epithelium. Infect. Immun. 16:766-772.

7. Gesner, B., and L. Thomas. 1966. Sialic acid binding sites: role in hemagglutination by Mycoplasma gallisepticum. Science 151:590-591.

8. Gibbons, R. J., and J. van Houte. 1975. Bacterial adherence in oral microbial ecology. Annu. Rev. Microbiol. 29:19-43.

9. Gorski, F., and W. Bredt. 1977. Studies on the adherence mechanism of Mycoplasma pneumoniae. FEMS Lett. 1:265-268.

10. Howard, C. J., R. N. Gourlay, and J. Collins. 1974. Serological comparison and hemagglutinating activity of Mycoplasma dispar. J. Hyg. 73:457-466.

11. Kahane, I., H. Furthmayer, and V. T. Marchesi. 1976. Isolation of membrane glycoproteins by affinity chro- matography in the presence of detergents. Biochim. Biophys. Acta 426:464-476.

12. Kahane, I., and S. Raxin. 1977. Cholesterol-phosphatidylcholine dispersions as donors of cholesterol to mycoplasma membranes. Biochim. Biophys. Acta 471:32-38.

13. Lowry, O. H., N. J. Rosebrough, A. L. Farr, and R. J. Randall. 1951. Protein measurement with the Folin phenol reagent. J. Biol. Chem. 193:265-275.

14. Manchee, R. J., and D. Taylor-Robinson. 1968. Haemadsorption and haemagglutination by mycoplasmas. J. Gen. Microbiol. 50:465-478.

15. Manchee, R. J., and D. Taylor-Robinson. 1969. Utilization of neuraminic acid receptors by mycoplasmas. J. Bacteriol. 98:914-919.

16. Marchesi, V. T., and E. P. Andrews. 1971. The use of lithium diiodosalicylate (LIS) to isolate glycoproteins from cell membranes. Science 174:1247-1248.

17. Powell, D: A., P. C. Hu, M. Wilson, A. M. Collier, and J. B. Baseman. 1976. Attachment of Mycoplasma pneumoniae to respiratory epithelium. Infect. Immun. 13:959-966.

18. Raxin, S., and S. Rottem. 1976. Techniques for the manipulation of mycoplasma membranes, p. 3-26. In H. Maddy (ed.), Biochemical analysis of membranes. Chapman and Hall, Ltd., London.

19. Sobeslaveky, O., B. Prescott, and R. M. Chanock. 1968. Adsorption of Mycoplasma pneumoniae to neuraminic acid receptors of various cells and possible role in virulence. J. Bacteriol. 96:695-706.

20. Somerson, N. L., W. D. James, B. E. Walls, and R. M. Chanock. 1967. Growth of Mycoplasma pneumoniae on a glass surface. Ann. N.Y. Acad. Sci. 143:384-389.

21. Taylor-Robinson, D., and R. J. Manchee. 1967. Adherence of mycoplasmas to glass and plastic. J. Bacteriol. 94:1781-1782.

22. Taylor-Robinson, D., and R. J. Manchee. 1967. Spermadsorption and spermagglutination by mycoplasmas. Nature (London) 215:484-487.

23. Warren, $L$. 1966. The thiobarbituric acid assay of sialic acids. J. Biol. Chem. 234:1971-1975.

24. Zucker-Franklin, D. M., M. Davidson, and $L$. Thomas. 1966. The interaction of mycoplasma with mammalian cells. I. HeLa cells, neutrophils and eosinophils. J. Exp. Med. 124:521-532. 